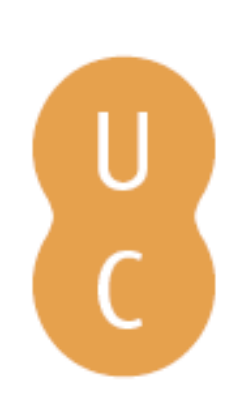

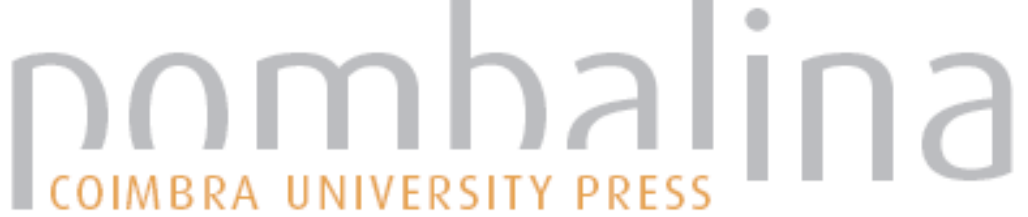

\section{Darwinists, but not much}

Autor(es): Jana, Alves

Publicado por: Imprensa da Universidade de Coimbra

URL persistente:

URI:http://hdl.handle.net/10316.2/31293

DOI:

DOI:http://dx.doi.org/10.14195/978-989-26-0342-1_18

Accessed : $\quad$ 26-Apr-2023 14:01:26

A navegação consulta e descarregamento dos títulos inseridos nas Bibliotecas Digitais UC Digitalis, UC Pombalina e UC Impactum, pressupõem a aceitação plena e sem reservas dos Termos e Condições de Uso destas Bibliotecas Digitais, disponíveis em https://digitalis.uc.pt/pt-pt/termos.

Conforme exposto nos referidos Termos e Condições de Uso, o descarregamento de títulos de acesso restrito requer uma licença válida de autorização devendo o utilizador aceder ao(s) documento(s) a partir de um endereço de IP da instituição detentora da supramencionada licença.

Ao utilizador é apenas permitido o descarregamento para uso pessoal, pelo que o emprego do(s) título(s) descarregado(s) para outro fim, designadamente comercial, carece de autorização do respetivo autor ou editor da obra.

Na medida em que todas as obras da UC Digitalis se encontram protegidas pelo Código do Direito de Autor e Direitos Conexos e demais legislação aplicável, toda a cópia, parcial ou total, deste documento, nos casos em que é legalmente admitida, deverá conter ou fazer-se acompanhar por este aviso. 
Ana Leonar Pereira João Rui Pita

Pedro Ricarda Fonseca (eds.)
Darwin,

Evalution,

Evolutionisms

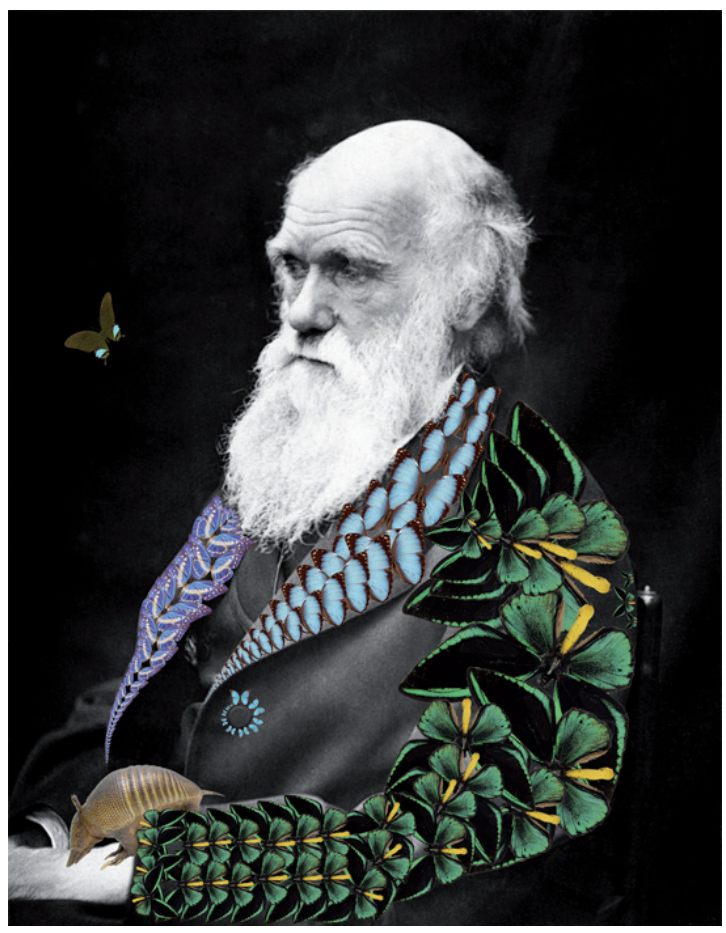


Alves Jana

Faculdade de Letras, Universidade de Coimbra, Portugal

\section{DARWINISTS, BUT NOT MUCH}

«Darwinism is just a scientific theory not yet proven.» This could be the beginning of an intervention at a congress on Darwin. But, undoubtedly, such a statement would not be adequate to the situation.

Actually, Darwinism is a well accepted scientific theory in the scientifically informed intellectual environment. Or better, in an intellectual environment equipped with a scientific culture and way of thinking.

However, if it is true that Darwinism is a generally accepted theory, it is not certain that it is accepted in all its consequences. In this case, we could say that we tend to be Darwinists, but not much. That is, because we accept the biological theory, but do not incorporate it, do not insert it in the way we think about things and the world beyond the specific environment of its genesis. As if we stated, in physics, that the Earth revolves around the Sun but continued to think of ourselves as the centre of the Universe.

Darwinism is a scientific theory. However, it is rooted in the general history of thought. As such, it is a scientific theory, but it is not just "one more" scientific theory. It is mainly a new paradigm, a new model of thinking about man and his place in the Universe.

Accepting Darwinism is overcoming the Platonic and Cartesian dualism. Since Plato man is thought of as a rational soul and material body. Or better, since Plato man is thought of as mainly an immaterial and rational soul. However, he is unfortunately imprisoned in a material body which is strange to him and from which he should free himself to become what he truly is, spirit. With Descartes, in the Modern Age, this paradigm of thinking about man maintained and reinforced itself with the assertion of a self transparent Cogito. Man continues to be seen as a different substance of the material world, a reality apart and of an immediate rational nature.

We know that this anthropological model was happily married to biblical tales until the $19^{\text {th }}$ century. It was then that things started to go wrong and the Cartesian Cogito was publically "humiliated". The roles of Nietzsche, Marx and Freud are recognized in this humiliation. Here, in particular, Darwin's action is of interest. But it is part of a continuous line which must include other scientists like Galileo and Newton, and, later on Gödel, Heisenberg, Konrad Lorenz and even António Damásio.

In succeeding steps, we shift from a paradigm of a man separated from nature to a man as an integral part of the only nature. In the same manner, we shift from an immediately rational and sovereign Cogito to a man that is flesh of the world, but that, through an evolutionary process, becomes rational and capable of more abstract and unpredictable behaviors from the most elementary levels of the evolutionary scale. 
In this new paradigm, man is not a reality apart from nature, nor does he belong to a metaphysical order. He belongs to a physical and biological world, and everything about him is the result of an evolution that produced music and religion, poetry and mathematics and even evolutionary theory itself.

Accepting Darwinism is not just accepting a scientific theory and functioning with it inside the domain of biology. It is to change the paradigm and take due anthropological consequences. It is to refuse a dualist anthropology of thousands of years of tradition and adopt a new anthropology. A new anthropology which is necessary to build from and beyond a way of thinking that is rooted in the most various domains of western thought as well as from the practices of that thought. It is important to highlight that for 2500 years we have been thinking of man and acting in the world according to a dualist matrix, which is why this way of thinking and acting has shaped Western intelligence itself and became the own nature of Western thought. Darwinism is, therefore, a challenge to rethink all that we have come to think and do for 2500 years inside the metaphysical and dualist matrix that has, in the meantime, gone through a radical crisis.

We have to think about man beyond this crisis. We have to rethink man's status towards himself and towards the History of evolution of which he is a part. We have to think about the status of Reason itself.

Let us briefly remember that even the Cartesian Cogito was geometric, aiming for clarity and distinction, in a thought process in which evidence was the rule of distinction between all and nothing. The truth, or better, the Truth was rational, clear and distinct, therefore absolute and a-historical. The rational view was panoptic and absolute in an undeniable universality. And Science (necessarily with capital letter) was an absolute knowledge and, therefore, definite in its undeniable universality. And Man, also with capital letter, was by nature Lord of the Universe and, by the power of Cogito, a creator, or even better, a pantocrator, capable of sovereignly dominating the World and putting it to his service. And, due to the absolute nature of the Cogito, this adventure could only have a happy ending, with the construction of Paradise on Earth, not on the uncertain hereafter.

However, World War I and World War II showed that this new religious faith gave us Hell more easily than the promised Paradise. And the atomic bomb showed that human intelligence is as much constructive as it is destructive. And the obvious ecological catastrophe showed that sovereign intelligence was mainly the arrogance of a-critical intelligence, incapable of knowing its limits.

The Cartesian Cogito is dead. But its lost soul still roams inside our way of thinking concretely. As if Darwin had never existed.

We continue to suppose that there is a transcendent order that guarantees that things are as "they should be" and "will be". So, we excuse ourselves from doing what needs to be done, because we believe that what happens is the result, not of what we do or of the present forces, not of our work and our organization, but of a superior order that rules what happens and from which we can, we have the right to expect, what we want to happen.

We continue to speak as if we held the entire Truth. In fact, we do not understand, in the world of knowledge and lively action, that all the affirmation is just of a superior animal on two legs, equipped with a brain, capable of rationalizing a point of view, 
always a point of view, always from his place in the world. That is why, we continue to speak as if we had a panoptic point of view, exterior to and above the world.

We continue to assert man as a rational being, when everything shows that he is, above all, a living being, an animal that lives and feels, and can achieve certain levels of rationality that do not revoke but might integrate his sensitivity.

We continue to insist on a clear and distinct discourse, confusing truth with the so-called rational. We forget that what is said is always a Siamese brother to what is not said. Moreover: that which is not said, therefore the unknown, is always more extensive and more decisive than what is said and known. The history of sciences itself should have taught us, over the last two hundred years, to look at the following two hundred years of science and, thus, diminish the relative importance of what we are proud to know today.

The Japanese, who did not have Plato and Descartes, did not need Darwin to figure out that what is too clear ofuscates and blinds more than it enlightens and allows to be seen. Father Arrupe, superior general of the Jesuits, said that it was frequent for a Japanese catechumen to object towards a systematic exposition: «Father, that which you are explaining is too clear to be true.» ${ }^{1}$ That is precisely why, Easterners always mantain what is not said as an important part not to forget with what is possible to say. And Paul Ricouer, for example, said long ago that only narratives can say what Wittgenstein advised to silence.

We continue to want to know just through the discourse we make and not, never, through what the silence can reveal and the discourse can never say. Annie Lehmann says that she and her husband refused the diagnosis that nothing could be done to recover their son Jonah from profound autism and did everything they could for him to have access to what they wanted for him. They eventually had to surrender to the evidence of failure. Looking at her own story of a tireless mother, Annie reflects: «Jonah turned 25 last Fall, and when I look at him, I can't help wondering if the past years weren't some Heaven-directed scheme meant to humble us and teach us the value of acceptance.» Understanding that we couldn't change him had changed us.» Regarding Jonah, she tells us: «He remains a man of very few words. But though it took us years, we have finally learned that there was something to hear in his silence.»

We continue to think of intelligence as a metaphysical characteristic and intrinsic to the rational animal that is man and not as an ability to solve problems, phylo and ontogenetically constructed, that we can find, larger in some cases and smaller in others, in a person, organization or community. In the same way, after having evaluated for a long time the Western culture as evidently superior, we continue to evaluate that all cultures are evidently equal, as if culture was not a collective construction to solve collective problems in which value lies in and is measured by its ability to solve these problems.

We continue to think of politics as if social reality were ruled by metaphysical forces independent from the reality of facts. Much of the criticism that is done has the Platonic paradigm of the world of ideas as a basis. A criticism is always mainly

${ }^{1}$ Juan Masiá and Kotaró Suzuki, O Dharma e o Espirito: Diálogos entre um cristão e um budista, Coimbra, Angelus Novus, 2009, p. 94. And Juan Masiá, author of this work also says that his Japanese students objected "Your explanation is too clear to be true.» (Idem) and that a Japanese teacher of floral arrangements said to a student of hers "Your arrangement is too symmetrical to be beautiful.» (Idem). These are manifestations of a non Cartesian, non geometric way of thinking at least not in an Euclidian geometry. 
the evidence of a certain criteria that underlines criticism. So, much of the criticism is still made from a Platonic paradigm of a "world of ideas" that is independent to the world of things. A paradigm that is not even Cartesian, because if it were, it would know that the facts of the world occur according to the laws of happening and not according to the abilities of reasoning.

We continue to think of education in a Cartesian format. Rational minds learn by evidence through a rational discourse of demonstration carried out by the teacher. Hence the magisterial, discursive teaching. Hence the fact that the body of the student behaves better the more absent it is. And the room is more organised if it has less action; Reasoning, which has nothing to do with the rest of the body, remains apart.

We continue to emphatically condemn religion, despite being universal in time and space, in direct proportion to its inability to show scientific evidence. Maybe Darwinism made us think of it in regard to an evolution which made man a religious being. Maybe Darwinism advised to think of religion more as a natural and cultural phenomenon as well, resulting from evolution itself. But that is unnecessary, in fact, it is forbidden, in the environment of a scientific positivism. That is also why we continue to think of spirituality as a sub product of ignorance instead of thinking of it as an area of activity which has a natural place in the process of life of a human being.

We continue to think of justice based on a Cartesian anthropology, in which principles and decisions are valued independently of a person's behaviour in a given situation. Wittgenstein had a Cartesian dream that he expressed in Tractatus: that it was possible to create a verbal 1 to 1 map, in which reality was represented point to point in language. Later, reality hit him and he saw that that was not possible. $\mathrm{He}$ even understood that there is no intrinsic rationality in the reality that can be expressed in an intrinsic rationality of language. But our justice still reads Tractatus, still hopes that the justice system represents the social reality point to point; and believes that the world conforms naturally and spontaneously to the supposed rationality of the way the courts function. Therefore, it is enough to judge according to the Law, for the world to remain in good order.

We mantain the secular division between science and technique on the one hand and human sciences and arts on the other. Each of the parts knows it has the Truth and thinks that the other is logically wrong from its roots. Darwinism advised to think of culture as a product of evolution, just like the sciences. But our liking for the absolute condemns us to the opposition between knowledges and powers.

We continue to think within the Cartesian Cogito model because we cannot yet get out of it. We cannot yet build an integral man, a man who, being an animal of evolution, has rational abilities to operate on and from his biological systems. In spite of António Damásio and many others having shown that the complete man cannot be thought of in terms of pure rationality.

This means we are Darwinists, but in the Cartesian sense: as if we had joined a rational discourse in a scientific context, without having incorporated it in the personal and collective system of thought and action in the world. Darwin has not happened yet.

Darwin's year is a good opportunity to reaffirm the recognition of the evolutionary theory. But, and this is what is more important now, it is an opportunity to extract from evolutionism the necessary consequences regarding what we are and how we think of ourselves and the world. And this is a work which is, in great part, yet to be done. 